\title{
Special Services in Liberal Arts College Libraries
}

Mrs. Sellers is chief special services librarian, Brooklyn College Library.

7 HANKs to a growing awareness on the 1 part of library administrators and the publicity given such activities by awards like the John Cotton Dana Publicity Award and the Library Public Relations Council Award, special services are beginning to come into their own. Many college and university libraries have tried to provide these strategic services, but they have too frequently assigned them to traditional departments. There they have been relegated to a secondary place.

Special services are not as firmly entrenched as are other types of library activity, but they are no less important. A collection may be assembled with great care and foresight but it is serving no useful purpose if its resources are incompletely tapped, either because of a lack of publicity on the part of the library, or a lack of working knowledge on the part of the prospective borrower. This was the conviction that prompted H. G. Bousfield, chief librarian at Brooklyn College to establish in 1948 the Special Services Divi$\operatorname{sion}^{1}$ as a separate library unit.

The primary purpose of the division is to act as liaison between the library and the public it serves. It operates in the following areas: public relations and publicity, exhibits, library publications and orienta-

1 The Library of Brooklyn College is an academic department. The individual units in it are therefore called "divisions" to prevent confusion.

[Editor's Note: Brooklyn College Library was the recipient of two awards in June, 1952; the annual award of the Library Public Relations Council and an Honorable the Library Public Relations Council and an Honorable
Mention in the John Cotton Dana Publicity Contest.] tion (tours and lectures). Since there are many libraries which do not engage in these activities at all, perhaps a brief explanation and some indication of their scope at Brooklyn College will be helpful.

\section{Public Relations and Publicity}

Publicity releases, leaflets, signs and posters keep students and faculty informed of the library's activities, of new services, and of changes in its policies and hours. At Brooklyn College, library news is submitted for each issue of all the campus publications-the day and evening session student papers, the sober faculty bulletin, and the less formal faculty newsletter. These releases, which herald the library's hopes and plans, as well as accomplishments, have paid dividends in campus interest and in the sympathetic treatment the library receives in print. Student journalists are encouraged to come for interviews and are provided with material for feature articles.

The department participates actively in planning for the reception of visitors, whether they are foreign librarians, library school students, or children from neighboring schools who have come to see the exhibits. Professional visitors are provided with copies of the library's publications in which they have a particular interest.

A special effort is made to engage the library in cooperative enterprises with other academic departments on the campus. Such activities as, for example, a vocational panel in librarianship, with the Department of Personnel Service, and the library lecture program with the English Department. 
Desirable library-faculty relations are also fostered through library-sponsored symposia, which bring off-campus experts to the college. One such occasion was a program on the selection and use of audiovisual materials, which was launched by the library to meet an urgent need for information in this important field.

Copy on all items likely to be of interest to the library world is sent to the professional periodicals. This may range from short items about personnel, symposia, publications, and new, time-saving devices, to complete articles. A publicity scrapbook is maintained, which contains programs, articles, publications, pictures and clippings.

\section{Exhibits ${ }^{2}$}

The Chief Special Services librarian organizes, schedules, and supervises all exhibits displayed in the library entrance hall, whether library-assembled or arranged by student groups and college departments. The response to the invitation to use these facilities is generally such that space usually has to be arranged for several months in advance of exhibit time.

Even special and fixed occasions are provided for (i.e. the Romance Language Department usually wants the two weeks including Pan American Day; the Shakespeare Club, the two weeks including the dramatist's birthday, etc.). The library assembles exhibits whenever there is unassigned time (usually this means the summer months), when an occasion is not included within any one department or club's province (i.e. Honors Day) or when a scheduled group discovers at the eleventh hour that it is not quite ready to exhibit.

There are very few such defaults, thanks to a combined code-and-application form evolved by the Chief Special Services librarian, one copy of which remains on file,

2Cf. Sellers, Rose Z., "Exhibits Can Be Easy," Wilson Library Bulletin, 23 :526-7, March, 1949. while the carbon is turned over to the student exhibit chairman to remind him of the date and of the restrictions connected with the privilege of using the cases.

A news release on each exhibit is sent to all four of the college's publications. If it appears in print, a copy of the issue containing the account is sent to each exhibit chairman, earning good will for the library. Wherever the exhibit warrants it, pictures are taken and submitted, with appropriate text, to interested library journals.

\section{Library Publications}

The Special Services Division edits, designs the format of, and arranges for the distribution of two handbooks-one designed for the students and the other for the faculty. The student publication is distributed to each freshman as part of the library lecture. Whenever a revision of the faculty handbook appears, copies are sent through the college mail to each member of the staff. Thereafter it is distributed only to newcomers. The chief of the division also edits the Staff Bibliography, an annual compilation of books, articles, abstracts, reviews, etc. published by the college staff during the last calendar year. In addition to these recurrent items, the department also explores the need for additional publications to serve a special purpose. It published, for example, Facts About Brooklyn College Library, a pamphlet designed to be sent to other libraries and agencies when they wrote asking about our plant, organization, source of funds, book stock, special collections, etc. It thus obviated the need for an individual reply to each questioner. Another such item was the $O$ pen Letter, which was created to show the students that the library was aware of their difficulty in obtaining some types of material, and to indicate to them how we planned to solve these problems, or why we could not. 


\section{Library Instruction ${ }^{3}$}

The student's first introduction to this library takes the form of a half-hour orientation tour, with the scheduling and briefing of the tour guides done by the Special Services Division. The tour generally takes place during registration week.

Beginning with the fourth week of the semester, after the term reports have been assigned, and help is welcome, the division arranges for each student in English $I$ to receive a lecture on the use of bibliographical tools, with special emphasis on the techniques of research in the preparation of term papers. The lectures are given by librarians. The subjects covered are: the catalog (types of author entry, title card as main entry, title card as secondary entry, periodical card, subject card); bibliographies and indexes (for whole books, parts of books, periodicals, government documents); steps in looking up material on a subject; how to assemble a bibliography; special reference services. The lecture is illustrated with the library's own slides. Each student receives a copy of the student library handbook, (which can be used for review), and is required to fill out a problem sheet on the material covered in the lecture. The problem sheet serves not only as a follow-up, but also to indicate to the lecturer whether there are still any special areas of difficulty.

The scheme of assigning the foregoing as primary functions to a separate division, with its attendant saving of time through the dovetailing of duties, having worked out so well here, it occurred to the Chief Special Services librarian that it would be of interest and value to the profession, if a study were made of how these activities are controlled in other college libraries. A questionnaire was therefore submitted to the

\footnotetext{
${ }^{3}$ Cf. Sellers, Rose Z.. "Library Instruction at Brook lyn College," Wilson Library Bulletin, 22:618-20, April. I 948 .
}

chief librarian in 200 selected liberal arts colleges. Of those, I 55 responses or 77.5 per cent were received.

\section{Exhibits}

To the question, "Does your library hold exhibits?" I 29 answered YES, 22 answered NO. The I 29 answered as follows to the question, "Are they the responsibility of the professional staff?": YES-II7, NO-2, PARTIALLY - IO. (In the case of the last-mentioned, responsibility is shared either between professional and non-professional members of the staff, or between the professional staff and other departments).

Among the II 7 who responded YES, in no case is responsibility for exhibits the full time job of any one librarian. The supervisor of exhibits also discharges one of the following functions:

reference librarian $\ldots \ldots \ldots \ldots \ldots \ldots \ldots .32$

circulation librarian ............. 16

chief librarian or director of libraries .... I 5

special collections or rare book librarian ... 7

catalog librarian ............... 4

associate librarian or adminstrative

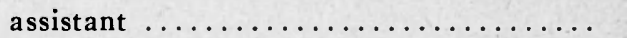

miscellaneous (film librarian, social science

librarian, library science instructor, arts

division librarian, subcommittee of fac-

ulty library committee, etc.) ..........

In 9 libraries, a staff committee assumes the function and in $2 \mathrm{I}$ libraries, the responsibility is rotated at given periods among the members of the staff. Of the 2 libraries which indicated that non-librarians assume full responsibility for exhibits, in one case it is assigned to a clerk and in the other, to the Art Department.

"Do you permit the exhibit cases to be used by non-library groups (i.e. student organizations, academic departments, community) ?" was answered YES, 99, NO, 30.

Among the 99 who permit non-library personnel to make use of their exhibit facilities, permission is granted as follows: 
academic departments and students

organizations

academic departments only ..............

any college-connected group (above, plus ad-

ministration, learned societies, Red Cross,

etc. Three of this group also gave ex-

hibit privileges to townspeople) ........

The same 99 answered as follows to the question, "Do you have a set of standards or a code that exhibitors must abide by?": $\mathrm{YES}-4 \mathrm{I}, \mathrm{NO}-58$.

Among the 4I respondents who answered in the affirmative, only 2 use a code that is in written form. The others rely on a trial lay-out, constant supervision, or a review by the supervisor, to insure good taste, use of library materials, etc.

\section{Library Publications}

"Does your library issue any publications (i.e. faculty and student library handbooks, recent accessions lists, bibliographies) ?" was answered in the affirmative by I 3 I libraries; 20 indicated no activity.

With regard to the editorship, I24 libraries turn this work over to the professional staff exclusively. In 6 libraries the work is done co-operatively by or distributed among librarians and members of other departments, or librarians and clerks. In a seventh the editing is done by the Division of Special Services of the college, not the library. These 7 libraries are therefore omitted from the tally of the next question: "Is editing publications one individual's fulltime job?". To this question only one library answered YES. In the remaining I23, the situation is as follows: in 2 libraries, publications are assigned to committees made up from the professional staff; in 32 libraries, the head librarian or director of libraries adds them to his administrative work; in the remaining 89 , the publications are added to the regular duties of librarians in appropriate departments, i.e. the handbook to Reference or to the Reader's Ad- visor, the accessions list to Circulation (or Catalog) etc.

"What publications does your library issue regularly?" was answered as follows: I03 libraries issue lists of recent accessions; I4 issue a combined recent accessions and library news sheet; 5 I publish a student handbook, while 7 provide one for the faculty. Nineteen libraries publish a newsletter designed for staff or faculty or both; I 7 issue bibliographies and booklists; 12 issue occasional papers ; 4 distribute classified lists of periodicals; one compiles a bibliography of faculty publications and 2 publish a bulletin for their "Friends." (Organizational charts and annual reports were not tallied.)

\section{Library Instruction}

Only 3 of the I 5 respondents answered NO to the question, "Does your college offer instruction to students on library usage and/or bibliographical techniques?"

On the next question, whether the instruction was formal, the surveyor had frequently to interpret the answer in the light of subsequent information, since many of the respondents answered both YES and NO. Those libraries which offered only a library tour, with the latter merely an introduction to the physical plant, were included with the NOES. So also were those libraries where there was no instruction other than individual guidance from librarians at public desks, scattered lectures given on invitation of instructors, or where the procedure varied too much from time to time to be classified. These criteria brought the total of the NOES to $3 \mathrm{I}$.

In the II 7 libraries where the instruction was judged to be "formal" 98 responded that instruction is given by librarians exclusively. (Instructors in library science were considered librarians.) In 8 libraries, instruction is given cooperatively by librarians and teachers, and in $I I$, it is offered by teachers only. Of the I9 li- 
braries where teaching departments are involved in library instruction, in every case where the teaching department was identified ( 16 ), it was the English Department.

Among the 98 who responded that library instruction is done entirely by professional librarians, 4 indicated that this function constitutes a full-time job for the person or persons involved. Among the 94 who answered that this is added to other regular duties, the distribution among the library departments is as follows:

entire professional staff ............ 34

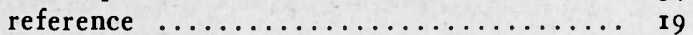

chief librarian or his assistant ......... I4

chief librarian or assistant and reference .. 7

reference and circulation ............. 3

reference and acquisition ............. 3

reference and catalog ............. 3

circulation $\ldots \ldots \ldots \ldots \ldots \ldots \ldots \ldots \ldots \ldots, 3$

catalog ..................... 2

catalog and chief librarian $\ldots \ldots \ldots \ldots \ldots$ I

bibliographer $\ldots \ldots \ldots \ldots \ldots \ldots \ldots \ldots \ldots$ I

education librarian $\ldots \ldots \ldots \ldots \ldots \ldots \ldots$ I

not indicated .................. 3

\section{Public Relations}

Here again, the responses were not only a definite YES or NO, but a yes-and-no, which the surveyor attempted to interpret. The last group's indecision usually stemmed from the fact that the public relations program was not formalized. Wherever the subsequent explanation of the activities warranted it, the yes-and-no responses were classified as YES. In any case where the respondent checked either YES or yes-andno but gave no further details, or insufficient details on which to base a judgment, the return was classified as NO.

Also classified with the NO group, were those libraries which indicated that they had no program separate from that of the College Public Relations Office or News Bureau. This held true regardless of whether the respondent had checked YES or $\mathrm{NO}$, for the surveyor was interested in the public relations program only if it was carried out by the members of the library staff, whether professional or nonprofessional. If the library used the Public Relations Office for press releases only and engaged in other public relations activities on its own, its return was classified as YES. Totals: YES, 6I ; NO, 90.

The wide interpretation given this item ("all our activities have a public relations angle") was reflected in the answers to the next question, which asked for a listing of the activities engaged in. Many libraries understandably listed exhibits, handbooks and lectures as integral parts of their program, but since these were tallied before, no separate account was kept in this section. A number of respondents, after listing specific activities, used the occasion to emphasize the admitted fact that genuine servicemindedness on the part of the staff was the most immediate avenue for good public relations. One (questionnaire-weary?) respondent listed "filling out questionnaires" as part of his public relations job.

Among the activities most frequently mentioned were:

releases to student news publications and in-

terviews with reporters $\ldots \ldots \ldots \ldots \ldots \ldots 44$

to community newspapers $\ldots \ldots \ldots \ldots \ldots \ldots \quad 32$

tours for visitors .............. 31

book talks to students, faculty or community 7 participation in radio programs ........ 6 host to library organizations .......... 5 lectures and teas for "Friends" groups ..... 5 suggestion box $\ldots \ldots \ldots \ldots \ldots \ldots \ldots \ldots{ }_{3}$

All of the 6r libraries who were judged to have a public relations program answered YES to the question of whether the program in the library is carried on by librarians. In no case is public relations one librarian's full-time job. That service is distributed among the staffs as a whole or added to duties of individuals as follows:

chief librarian (One wrote plaintively "The

librarian is a busy guy") ........... 25 whole staff or committee from whole staff 24 associate librarian ............... 5 chief librarian and associate librarian ..... 4 chief librarian and reference assistant .... 2 reference librarian $\ldots \ldots \ldots \ldots \ldots \ldots \ldots$ I 
The Desirability of a Special Services Department

The respondents were asked to indicate whether, if it were possible for them to do so, they would relegate all the special activities (exhibits, publications, library instruction, public relations) to a separate Special Services Department. The answers were YES, 45 ; NO, 83; Undecided, II ; No answer, I 2.

Those who answered $\mathrm{NO}$ were asked to give their reasons. It soon became apparent that many had said NO under the mistaken impression that the proposed new department would be composed of non-librarians, whose interest would be synthetic because they are not in close touch with the substance of library procedures. (However, they are included with the other NOES).

The reasons for not wanting a Special Services Department fell mainly into three categories. The largest number (27) felt that their library was too small, or that there was not enough activity of this nature to warrant such a department. The next group (22) indicated that they preferred to have the entire staff participating in all these activities so as to broaden their background and add variety to their assignments. The third group (7) were a special joy to the surveyor (who, together with a parttime assistant constitutes "a Special Services Department"). Their reason was that no one person could possibly have all the qualifications needed for such varied, activities. The most appealing NO was provided by one chief librarian who announced "Have too much fun doing it myself." No reason was given by the remaining NOES.

\section{Aladdin's Lamp}

"If a Foundation were to provide the funds for equipment, staffing, etc., what library project or activity would be your first choice?" Thirty-four librarians did not answer this question. In the case of the I 7 who did, the answers were as varied as they were interesting. (Many asked for several things so the total will be more than the II 7 responding).

The need that appeared most frequently (2I times) was for library instruction: to establish it, expand it, or have the library take it away from the English Department. Tied for second place (with I7 requests) was the desire for an Audio-Visual Bureau or department and for a new library building or extension; i I respondents asked for more money for staff and books generally, while Io wanted it specifically so as to bring their cataloging up-to-date or to change from one classification scheme to another; 9 indicated the need of someone to take care of public relations and publicity; 8 wanted to inaugurate or expand a microfilm or microcard project; 6 asked for a music collection with listening facilities. The same number wanted a Special Services Department to provide for all the activities mentioned in the questionnaires. There were 5 requests for each of two publications -a student handbook and a library publication (house organ). Studies suggested were the following: the cost of processing library materials, the cost of storing them, the desirability of the open stack system. Three wanted exhibit facilities and personnel. Two wanted a lecture series underwritten. The same number also asked for funds to develop special regional collections. The singles ranged from air conditioning through bibliographic control of current scientific and technical publications.

Perhaps the wistful tone of many of the answers can best be expressed by the two words which appeared below one request: "Any chance?" 